\title{
ANALISIS KADAR KALSIUM OKSALAT PADA BATU GINJAL
}

\author{
Ni Made Sri Handayani \\ Universitas Pendidikan Ganesha \\ Singaraja, Indonesia \\ e-mail: handay_sri8@gmail.com
}

\begin{abstract}
Abstrak
Penelitian ini adalah penelitian deskriptif yang bertujuan untuk (1) mengetahui persentase batu ginjal yang mengandung kalsium oksalat, dan (2) rentangan kadar kalsium oksalat pada batu ginjal yang positif mengandung kalsium oksalat. Subjek penelitian ini adalah batu ginjal, sedangkan objek penelitian ini adalah kadar senyawa kalsium oksalat pada batu ginjal. Penelitian ini dilakukan di Laboratorium Patologi Klinik Rumah Sakit Sanglah Denpasar dari tanggal 3 Mei 2005 sampai dengan 25 Juni 2005. Hasil penelitian menunjukkan bahwa (1) persentase kadar kalsium oksalat pada batu ginjal adalah sebanyak $75 \%$ dan (2) rentangan kadar kalsium oksalat pada batu ginjal yang positif mengandung kalsium oksalat adalah $30 \%$ sampai $81 \%$.
\end{abstract}

Kata kunci: Batu Ginjal, Kalsium Oksalat

\section{Pendahuluan}

Batu ginjal merupakan partikel padat menyerupai kerikil yang terdapat di berbagai sistem kemih seperti ureter, pelvis dan kandung kemih. Senyawa-senyawa penyusun yang biasanya ditemukan dalam batu ginjal adalah kalsium oksalat, kalsium fosfat (brusit), asam urat, sistin, struvit $\left(\mathrm{MgNH}_{4} \mathrm{PO}_{4}\right)$ dan wedelit (Bakta, 1995).

Batu ginjal merupakan penyebab terbanyak kelainan saluran kemih. Di beberapa rumah sakit di Indonesia dilaporkan ada perubahan proporsi batu ginjal dibandingkan batu saluran kemih bagian atas. Dari hasil analisis jenis batu ginjal di Laboratorium Patologi Klinik Universitas Gadjah Mada tahun 1964 dan 1974, dijumpai ada kenaikan proporsi batu ginjal dibandingkan proporsi batu kandung kemih. Sekitar tahun 1964-1969 didapatkan proporsi batu ginjal sekitar 20\% dan batu kandung kemih sebesar 80\%, tetapi pada tahun 1970-1974 didapatkan batu ginjal sebesar $70 \%$ dan kandung kemih sebesar $30 \%$.

Menurut penelitian beberapa ahli medis, dari 96 buah batu ginjal yang ditemukan mengandung kalsium oksalat tinggi, yaitu sekitar $70-76 \%$, kemudian sekitar $5-20 \%$ mengandung asam urat, struvit $\left(\mathrm{MgNH}_{4} \mathrm{PO}_{4}\right)$ sekitar $10-17 \%$ dan batu sistin sebesar $1-3 \%$ (Sukahatya dan Muhamad Ali,1975).

Di beberapa rumah sakit di Indonesia dilaporkan sekitar 75-85\% dari batu ginjal merupakan batu kalsium oksalat, dimana batu ini adalah kombinasi dari kalsium dan oksalat yang timbul akibat kandungan zat tersebut yang terlalu banyak didalam urin. Meningkatnya kadar kalsium oksalat dalam urin dapat berasal dari konsumsi makanan yang memiliki kandungan kalsium dan oksalat yang tinggi. Individu yang menetap di daerah beriklim panas dengan paparan sinar ultraviolet tinggi akan cenderung mengalami dehidrasi serta peningkatan produksi vitamin D3 (yang dapat memicu peningkatan ekskresi kalsium oksalat), sehingga insiden batu saluran kemih akan meningkat.

Dari uraian di atas terlihat bahwa batu ginjal merupakan penyebab utama kelainan pada saluran kemih, kalsium oksalat merupakan senyawa penyusun batu ginjal yang paling sering ditemukan. Dengan demikian, jika terdapat kelebihan kalsium oksalat maka peluang terbentuknya batu ginjal besar. Oleh karena itu, perlu dilakukan penelitian tentang persentase batu ginjal yang mengandung kalsium oksalat dan rentangan kadar kalsium oksalat yang terdapat pada batu ginjal tersebut, untuk mencegah terbentuknya kembali batu ginjal khususnya yang mengandung senyawa kalsium oksalat. 


\section{Metode}

Ditinjau dari sifat dan tujuannya penelitian ini bersifat diskriptif yaitu mencari persentase batu ginjal yang mengandung kalsium oksalat dan rentangan kadar kalsium oksalat pada batu ginjal yang positif mengandung kalsium oksalat. Pada tahap persiapan bahan yang datang di bersihkan dari kotoran-kotoran yang melekat, kemudian dilakukan pemeriksaan makroskopis yang meliputi berat, warna, jumlah, dan tampang permukaan. Tahap selanjutnya adalah menganalisis kadar anion dan kation batu ginjal tersebut. Persentase senyawa pada batu ginjal dicari dengan menggunakan tabel senyawa batu ginjal yang kemudian data yang didapatkan dijumlahkan dan dikalikan $100 \%$ sehingga didapatkan persentase kadar senyawa batu ginjal.

Penelitian dilakukan di laboratorium Patologi klinik Rumah Sakit Sanglah Denpasar dari tanggal 3 Mei sampai dengan tanggal 2 Juli 2005. Waktu pelaksanaan penelitian bersamaan dengan pelaksanaan Kerja Praktek peneliti di Rumah Sakit Sanglah Denpasar.

Subjek penelitian adalah batu ginjal dari pasien penderita batu ginjal di laboratorium Patologi Klinik Rumah Sakit Sanglah Denpasar dari tanggal 3 Mei sampai dengan 25 Juni 2005.

Objek penelitian ini adalah kalsium oksalat pada batu ginjal dari pasien penderita batu ginjal di Laboratorium Patologi Klinik Rumah Sakit Sanglah Denpasar dari tanggal 3 Mei sampai dengan 25 Juni 2005.

Instrumen yang digunakan untuk mendapatkan data kadar kalsium oksalat pada batu ginjal adalah gelas kimia, gelas nessler, penggerus, $\mathrm{pH}$ meter, batang pengaduk, spatula, tabel khusus analisis.

Bahan yang digunakan adalah sebagai berikut. 1) Asam sulfat pekat $\left.\left(\mathrm{H}_{2} \mathrm{SO}_{4}\right), 2\right)$ Natrium hidroksida (NaOH) $27 \%$, 3) Asam kalkonkarboksilat (CaCHCOOCOOH), 4) EDTA, 5) Buffer Borat, 6) Besi (III) klorida $\left.\left(\mathrm{FeCl}_{3}\right), 7\right)$ Asam sulfosalisilat $\left\{\mathrm{HO}_{3} \mathrm{~S} \mathrm{C}_{6} \mathrm{H}_{3}(\mathrm{OH}) \mathrm{COOH}\right\}$

Data yang diambil dari penelitian ini adalah data hasil pemeriksaan pasien yang menderita penyakit batu ginjal yang masuk dari tanggal 3 Mei sampai dengan tanggal 2 Juli 2005 di Laboratorium Patologi Klinik Rumah Sakit Sanglah Denpasar. Persiapan yang dilakukan oleh peneliti dalam tahap ini adalah sebagai berikut.

Data yang diperoleh dalam penelitian ini adalah data tentang kadar kalsium oksalat dalam batu ginjal pasien. Tahap-tahap pengumpulan data dilakukan dengan cara sebagai berikut. .

Pada tahap ini dilakukan persiapan alat, bahan dan sampel yang akan diperiksa. Langkah-langkah yang digunakan adalah sebagai berikut. a) Sampel batu ginjal pasien dicuci hingga bersih kemudian diidentifikasi secara makroskopis yang meliputi jumlah, besar/ukuran, warna dan tampang permukaan, b) Setelah dilakukan pemeriksaan makroskopis terhadap batu ginjal, kemudian batu ginjal dihancurkan dengan menggunakan penggerus dan dicampur dengan aqua steril agar homogen.

Pada tahap ini dilakukan penentuan kadar kalsium oksalat dan analisis kation dan anion penyusun batu ginjal. Langkah-langkah yang dilakukan adalah sebagai berikut. a) Diambil satu sendok sampel yang telah homogen dan ditambah dengan sedikit aqua steril, b) pH batu ginjal diukur dengan menggunakan $\mathrm{pH}$ meteri, c) Ditambahkan dengan aqua steril sampai volume $10 \mathrm{~mL}$, d) Disiapkan 2 tabung nessler untuk analisis kation-kation penyusun batu ginjal, e) Tabung diisi dengan larutan sampel sampai tanda batas, f) Dilakukan analisis adanya kalsium dan oksalat pada batu ginjal

Kalsium dapat bereaksi dengan EDTA membentuk komplek berwarna biru. Dengan asam Kalkonkarboksilat sebagai indikatornya.

\section{A. Prinsip Pemeriksaan}

Prinsip analisis kalsium dalam batu ginjal terbentuknya komplek ungu antara $\mathrm{Ca}^{2+}$ dengan asam kalkonkarboksilat. Titrasi dengan EDTA menyebabkan terbentuknya komplek CaEDTA. Titik akhir titrasi ditandai dengan terbentuknya warna biru.

Reaksi:

$$
\mathrm{Na}_{2} \mathrm{EDTA}+\mathrm{Ca}^{2+} \stackrel{\mathrm{NaOH}}{\longrightarrow} \mathrm{CaEDTA}+2 \mathrm{Na}^{+}
$$

Cara Kerja: a) Campuran sampel ditambahkan dua tetes $\mathrm{NaOH} 27 \%$, b) Ditambahkan satu sendok spatula kalkonkarboksilat, c) Diaduk hingga rata dan ditambah titrasi dengan larutan titriplex III sampai warna ungu berubah menjadi biru, d) Jumlah tetesan larutan titriplex III yang digunakan kemudian dikalkulasikan, satu tetes setara dengan $5 \%$ kalsium. 
Garam-garam oksalat dari logam-logam alkali dan besi (II) mudah larut dalam air, sedangkan semua oksalat yang lain sedikit atau tidak larut dalam air. Tetapi, semua garamgaram tersebut dapat larut dalam asam-asam encer. Oksalat dapat bersenyawa dengan kalsium membentuk kalsium oksalat.

\section{B. Prinsip Pemeriksaan}

Prinsip pemeriksaan adalah terbentuknya komplek berwarna antara kelebihan ferri yang digunakan untuk bereaksi dengan oksalat dengan asam sulfosalisilat.

Reaksi:

$$
\begin{aligned}
\mathrm{C}_{2} \mathrm{O}_{4}{ }^{2-}+\mathrm{Fe}^{3+}{ }_{(\text {berlebih) }} & \longrightarrow \mathrm{Fe}_{2}\left(\mathrm{C}_{2} \mathrm{O}_{4}\right)_{3} \\
\mathrm{Fe}^{3+}{ }_{\text {(sisa) }}+\text { Asam Sulfosalisilat } & \longrightarrow[\mathrm{Fe} \text { Sufosalisilat }]^{+} 2 \mathrm{H}^{+}
\end{aligned}
$$

Cara Kerja: a)_Pada campuran sampel ditambahkan dengan dua tetes buffer borat, b) Ditambahkan tiga tetes $\mathrm{FeCl}_{3}$ dan tiga tetes asam sulfosalisilat, c) Ditunggu dua menit dan warna yang terbentuk dibandingkan dengan skala warna yang ada

Persentase senyawa kalsium Oksalat dapat dicari dengan menggunakan Tabel Khusus komponen senyawa penyusun batu ginjal. Pertama-tama persentase ion kalsium dan ion oksalat yang didapatkan dari perhitungan eksperimen, dicocokkan dengan tabel khusus analisa senyawa batu ginjal. Untuk memperkirakan persentase kalsium oksalat dapat digunakan persentase anion atau kation yang terendah, kemudian dicocokkan dengan persentase kalsium oksalat. persamaan 1 .

Persentase kalsium oksalat tersebut kemudian dihitung dengan menggunakan

$$
\% \text { kadarsenyawa } \mathrm{CaC}_{2} \mathrm{O}_{4}=\frac{\% \text { senyawa } \mathrm{CaC}_{2} \mathrm{O}_{4}}{\text { jumlahtotal kadarsenyawabatu ginjal }} \times 100 \%
$$
persamaan 2.

Untuk mencari persentase batu ginjal yang mengandung kalsium oksalat digunakan

Persamaan 2.

$$
\% \mathrm{CaC}_{2} \mathrm{O}_{4} \text { pada batu ginjal }=\frac{\text { Batu ginjal yang mengandung } \mathrm{CaC}_{2} \mathrm{O}_{4}}{\text { jumlah total batu ginjal }} \times 100 \% \text {..(2) }
$$

Untuk menentukan rentangan kadar kalsium oksalat dalam batu ginjal yang positif mengandung kalsium oksalat dapat diketahui dari hasil perhitungan di depan dengan cara analisis secara kuantitatif.

\section{Hasil dan Pembahasan}

Hasil pemeriksaan kadar kalsium oksalat pada batu ginjal yang diperoleh dalam penelitian ini ditunjukkan pada Tabel 3.1

Tabel 1. Data Hasil Pengolahan Kalsium Oksalat

\begin{tabular}{ccc}
\hline No & Subjek & Kalsium oksalat $\left(\mathrm{CaC}_{2} \mathbf{O}_{4}\right)(\%)$ \\
\hline 1 & $\mathrm{~A}$ & - \\
2 & $\mathrm{~B}$ & 54 \\
3 & $\mathrm{C}$ & 30 \\
4 & $\mathrm{D}$ & - \\
5 & $\mathrm{E}$ & 75 \\
6 & $\mathrm{~F}$ & 81 \\
7 & $\mathrm{G}$ & 72 \\
8 & $\mathrm{H}$ & 75 \\
\hline
\end{tabular}


Untuk perhitungan persentase $\mathrm{CaC}_{2} \mathrm{O}_{4}$ disajikan pada Lampiran 3. Dari data pada Tabel 1 didapatkan Subjek batu ginjal yang positif mengandung kalsium oksalat adalah 6 buah. Dengan menggunakan persamaan 3.1 diperoleh persentase batu ginjal yang mengandung kalsium oksalat adalah sebesar $75 \%$, dengan kadar berkisar antara $30 \%$ sampai dengan $81 \%$.

Dari hasil analisis data diperoleh persentase batu ginjal yang mengandung kalsium oksalat adalah sebanyak $75 \%$. Hal ini sebanding dengan hasil dari penelitian yang dilakukan oleh dr Nico A. Lumenta, K Nefro dari RS Mediros yaitu sekitar 75-80\%. Sehingga dapat dikatakan bahwa penderita batu ginjal yang positif mengandung kalsium oksalat tergolong tinggi.

Dari hasil pemeriksaan pada Tabel 4.1 terlihat bahwa ada 6 batu ginjal yang positif mengandung kalsium oksalat. Dan rentangan kadar kalsium oksalat pada batu ginjal yang positif mengandung kalsium oksalat adalah $30 \%$ sampai $81 \%$ dengan rata-rata $55.5 \%$. Sehingga oleh pihak rumah sakit dapat digunakan sebagai bahan perbandingan untuk kasus yang sama dan dalam penanganan pengobatannya dapat dengan mudah dilakukan. Batu ginjal kemungkinan akan terbentuk bila dijumpai satu atau beberapa faktor pembentuk kristal kalsium dan menimbulkan agregasi pembentukan batu. Subyek normal dapat mengekresi nukleus kristal kecil. Proses pembentukan dimungkinkan dengan kecendrungan ekskresi agregat kristal yang lebih besar dan kemungkinan sebagai kristal kalsium oksalat dalam air kemih. Agregasi kristal menjadi cukup besar sehingga tertinggal dan biasanya ditimbun pada duktus kolektivus akhir, yang selanjutnya secara perlahan timbunan akan membesar.

Tingginya kadar kalsium oksalat pada batu ginjal disebabkan karena kelarutan kalsium oksalat dalam air sangat rendah $\left(\mathrm{Ksp}=2.10^{-9}\right)$ dan ekskresi kalsium ke dalam urin cukup tinggi. Ekskresi $\mathrm{Ca}^{2+}$ yang tinggi kedalam urin disebabkan kadar Ca dalam makanan yang dikonsumsi terutama protein, cukup tinggi. Sedangkan keperluan kalsium dalam tubuh sifatnya terbatas. Keperluan ion $\mathrm{Ca}^{2+}$ dalam tubuh bersifat terbatas (kadar normal $\mathrm{Ca}$ dalam darah adalah 8,1$10,4 \mathrm{mg} / \mathrm{L}$ ) sehingga kelebihan Ca yang dikonsumsi akan dibuang ke urin.

Tingginya kadar kalsium dalam air kemih disebabkan oleh beberapa faktor yaitu :

1. Hiperkalsiuria

Merupakan kelainan yang dapat menyebabkan hematuria tanpa di temukannya batu. Kejadian hematuria ini diduga disebabkan oleh agregasi kristal kecil. Peningkatan ekskresi $\mathrm{Ca}$ dalam air kemih dengan atau tanpa faktor risiko lainnya ditemukan pada setengah dari pembentukan batu idiopatik. Terbentuknya hiperkalsiuria idiopatik antara lain melalui: a) hiperkalsiuria absorptive, ditandai dengan adanya kelebihan kalsium dari lumen usus, b) hiperkalsiuria puasa, ditandai dengan kelebihan kalsium yang diduga berasal dari tulang, $\mathrm{c}$ ) hiperkalsiuria ginjal, disebabkan adanya kelainan reabsorpsi kalsium di tubulus ginjal.

\section{Hipositraturia,}

Merupakan penurunan ekskresi inhibitor pembentukan kristal dalam air kemih khususnya sitrat. Sitrat pada lumen tubulus akan mengikat kalsium membentuk larutan kompleks yang tidak terdisosiasi. Akibatnya kalsium bebas untuk mengikat oksalat akan berkurang.

\section{Hiperurikosuria} kalsium.

Merupakan peningkatan asam urat air kemih yang dapat memacu pembentukan batu

\section{Hiperoksaluria}

Merupakan kenaikan ekskresi oksalat diatas normal. Ekskresi oksalat air kemih memiliki kadar normal dibawah $45 \mathrm{mg}$ per hari. Peningkatan ekskresi oksalat yang rendah menyebabkan perubahan yang cukup besar pada air kemih dan dapat memacu presipitasi kalsium oksalat dengan derajat yang lebih besar dibandingkan kenaikan absolut ekskresi kalsium.

Jika meningkatnya kadar kalsium dalam darah melebihi kadar normal (8,1-10,4 mg/L) maka kelebihan kalsium yang dikonsumsi akan dibuang ke urin. Didalam urin kalsium oksalat akan diendapkan. Hal ini disebabkan karena ekskresi $\mathrm{Ca}^{2+}$ ke dalam urin yang tinggi dan kelarutan kalsium oksalat dalam air sangat rendah $\left(\mathrm{Ksp}=2.10^{-9}\right)$ Keberadaan batu ginjal pada bagian saluran kemih dapat menimbulkan rasa sakit yang luar biasa pada penderita. Secara umum upaya yang dilakukan untuk mengeluarkan batu tersebut dapat dilakukan dengan beberapa cara yaitu dengan banyak meminum air putih ditambah dengan ramuan tradisional 
seperti tumbuhan kumis kucing yang berkhasiat untuk melancarkan buang air kecil, tindakan penghancuran batu (litotripsi) dan dengan cara operasi. Akan tetapi batu ginjal yang telah dikeluarkan tersebut tanpa pencegahan dapat kambuh lagi. Oleh karena itu perlu dilakukan tindakan pencegahan timbulnya kembali penyakit pada saluran kemih. Untuk batu ginjal yang mengandung kalsium oksalat tindakan-tindakan yang perlu dilakukan untuk menanggulanginya adalah sebagai berikut: 1) Membatasi konsumsi masukan kalsium yaitu dengan mengurangi mengkonsumsi makanan dan minuman yang mengandung kalsium, seperti ikan salmon, es krim, susu, keju dan lain-lain, 2) Melakukan diet rendah oksalat yaitu sekitar 40 sampai $50 \mathrm{mg}$ per hari, 3) Meminum air sebanyak-banyaknya agar air kemih dapat keluar dengan lancar. Jumlah air minum yang dianjurkan adalah sejumlah yang dapat menghasilkan minimal 2 liter per hari dan terbagi rata selama sehari.

\section{Simpulan dan Saran}

Berdasarkan tujuan yang dirumuskan dan hasil penelitian yang diperoleh maka dapat disimpulkan sebagai berikut: 1) Persentase batu ginjal yang mengandung kalsium oksalat di RS Sanglah Denpasar dari tanggal 3 Mei sampai 25 Juni 2005 adalah $75 \%$, 2) Rentangan kadar kalsium oksalat pada batu ginjal yang positif mengandung kalsium oksalat yaitu $30 \%$ $81 \%$.

Adapun saran yang ingin disampaikan peneliti terkait dengan penelitian ini adalah. 1) Dilakukan penelitian serupa dengan sampel yang lebih banyak sehingga hasil yang di dapat lebih akurat, 2) Mengingat tingginya kasus penderita batu ginjal yang mengandung senyawa kalsium oksalat, maka perlu kiranya diberikan penyuluhan-penyuluhan kepada masyarakat tentang efek dari terlalu banyaknya mengkonsumsi makanan yang mengandung kalsium oksalat.

\section{Daftar Pustaka}

Anonim, Instalasi Laboratorium Patologi Klinik RS Sanglah Denpasar. 2004. SOP Klinik Rutin, Denpasar

Bakta, I Made. 1995. Ilmu Penyakit Dalam Dasar, Denpasar

Catur, Meiwanto. 2005. Batu Ginjal dan Pencegahannya, http//www. DetikHealt. Com. 5 September 2005

Putriningsih, Ayu Ni kade. 1998, Analisis Senyawa batu ginjal (tidak diterbitkan), UNPAD, Bandung

Senior. 2005. Kalsium Oksalat. http//www. Indomedia. Com, 5 September 2005

Sjamsuhidajat, R dan Wim de jong. 1997. IImu Bedah, Jakarta: Balai Penerbit FKUI

Soeperman dan Sarwono waspadji. 1990. IImu Penyakit Dalam, jilid II, Jakarta: Balai Penerbit FKUI 